\title{
PSIKOEDUKASI MANAJEMEN STRES PADA LANSIA DI WILAYAH PUSKESMAS RANGKAH, SURABAYA
}

\author{
Marsya Rezkita Dewi* \\ *Universitas Airlangga
}

DOI: https://doi.org/10.21009/JPPP.081.04

Alamat Korespondensi:

marsyarezkitadewi@gmail.com

\begin{abstract}
This psychological intervention aims to increase the knowledge of stress management among Rossela elderly community in Puskesmas Rangkah area, Surabaya by giving the psychoeducation about stress management. Proposed sampling was used as a technique sampling with 11 elderly as sample. The stress level of Rossela elderly community measured by Stress Assessment Questionnaire (SAQ) and the knowledge of elderly stress management measured by pretest-posttest questionnaire made by researcher. The result of intervention show positive effect by giving psychoeducation about stress management to the Rossela elderly community which the knowledge increases before and after giving psychoeducation and the effect size category is average (0.72).
\end{abstract}

Keyword:

Stress management, Elderly, Psychoeducation.

\section{Pendahuluan}

Departemen Kesehatan Republik Indonesia membagi kategori usia ke dalam beberapa kelompok, masa lanjut usia (lansia) pada kategori ini dimulai dari usia 46 hingga 65 tahun ke atas. Pada tahun 1998, World Health Organization (WHO) telah memperkirakan bahwa angka harapan hidup manusia yang tinggal di Indonesia akan semakin meningkat yang disebabkan adanya peningkatan pada taraf hidup dan pelayanan kesehatan yaitu angka harapan hidup manusia berubah dari usia 65 tahun pada 1997 menjadi 73 tahun pada 2025 (Ismayanti, Isnia, Puspitasari \& Susanti, 2015). Pada kenyataannya tahun 2018, pelayanan yang didapatkan oleh masyarakat di Indonesia belum dapat memenuhi seluruh kebutuhan yang menunjang tercapainya peningkatan harapan hidup seperti akses untuk melakukan pemeriksaan kesehatan, terdapat perbedaan kelas sosial ekonomi, dan tingkat pendidikan rendah.

Berdasarkan data Badan Pusat Statistik, pada tahun 2010 jumlah lansia yang terdapat di Indonesia sebanyak 23.992.552 jiwa $(9,77 \%)$ dan diperkirakan meningkat pada tahun 2020 sebesar 28.822.879 jiwa (11,34\%). Peningkatan jumlah lansia ini tidak berbanding positif dengan peningkatan kesejahteraan hidup karena sebanyak 2.426.191 jiwa (15\%) lansia memiliki kondisi kehidupan yang kurang baik seperti adanya lansia yang telantar tersebar di perdesaan maupun di perkotaan dan hal ini seringkali dikaitkan dengan faktor tingkat pendidikan rendah yang mengakibatkan kurangnya kemampuan untuk mensejahterakan hidup. Kondisi-kondisi demikian dapat menjadi salah satu penyebab stres pada masa lansia.

Stres merupakan bentuk respon tubuh yang diakibatkan karena tidak dapat memenuhi tuntutan beban yang ada, seseorang yang mengalami stres berupa distress akan 
menunjukkan gangguan pada salah satu atau lebih organ tubuh sehingga menyebabkan terganggunya fungsi seseorang secara fisik dan psikologis. Pada lansia, seseorang akan lebih rentan mengalami stres karena terdapat lebih banyak stressor seperti kondisi fisik dan motivasi yang menurun. Pada lansia, penurunan kesehatan fisik juga dapat terjadi sebagai akibat dari mengalami stres seperti kondisi keluhan somatik (Hidaayah, n.d).

Puskesmas Rangkah, Surabaya merupakan salah satu puskesmas yang sering kali menerima pasien lansia yang mengeluhkan beberapa keluhan fisik seperti nyeri dan pusing, akan tetapi setelah dilakukan pemeriksaan fisik tidak terdapat tanda penyakit fisik sehingga keluhankeluhan tersebut ditindaklanjuti dengan cara melakukan konsultasi psikologi dan ketika melakukan konsultasi psikologi, pasien-pasien lansia cenderung menceritakan keluhan psikis seperti ketakutan akan kematian, perasaan lelah mengurus cucu karena anak bekerja, dan kondisi ekonomi yang berada pada golongan rendah.

Berdasarkan gambaran di atas, dapat ditarik kesimpulan bahwa secara garis besar pasien lansia di Puskesmas Rangkah yang mengeluhkan kondisi fisik banyak yang berasal dari permasalahan psikis yang dapat menjadi tanda terjadinya stres. Banyaknya lansia yang tinggal di sekitar Puskesmas Rangkah, menjadi perhatian pemerintah sehingga di wilayah tersebut terdapat suatu paguyuban yang beranggotakan lansia. Paguyuban ini terdapat pada Posyandu Lansia yang bernama Paguyuban Lansia Rossela.

Paguyuban Lansia Rossela merupakan paguyuban yang beranggotakan lansia berusia 50 tahun ke atas yang tinggal di sekitar Puskesmas Rangkah, Surabaya. Pada paguyuban ini terdiri dari banyak latar belakang lansia seperti usia, sosial ekonomi, pekerjaan, gender, dan hobi. Paguyuban Lansia Rossela aktif mengadakan kegiatan untuk meningkatkan produktivitas anggotanya seperti kegiatan senam dan pemeriksaan kesehatan rutin setiap bulan. Kondisi inilah yang selanjutnya menjadi perhatian pemeriksa untuk melakukan intervensi komunitas Paguyuban Lansia Rossela karena pada paguyuban ini lansia melakukan banyak kegiatan positif yang dapat meningkatkan kesehatan fisik.

Kegiatan peningkatan kesehatan fisik ini akan lebih baik jika diiringi dengan adanyapeningkatan dalam bidang kesehatan mental karena di dalam tubuh yang kuat terdapat jiwa yang sehat sehingga salah satu kontribusi yang dapat dilakukan oleh pemeriksa sebagai tenaga psikologi ialah melakukan kegiatan intervensi komunitas lansia dengan cara memberikan psikoedukasi mengenai manajemen stres sebagai suatu upaya peningkatan pengetahuan lansia mengenai stres sehingga dapat mencegah terjadinya stres yang dialami oleh lansia. Tujuan lainnya ialah peserta diharapkan mampu menerapkan metode untuk mencegah dan/atau mengurangi gejala-gejala stres dengan cara penggunaan metode SEFT yang diberikan sebagai salah satu bentuk relaksasi saat memberikan psikoedukasi.

\section{Metode Penelitian}

Kegiatan intervensi psikologis ini menggunakan metode kuantitatif dan kualitatif. Metode kuantitatif dipilih untuk mengetahui keberhasilan intervensi yang diberikan dan metode kualitatif digunakan untuk mengetahui data diri responden serta dalam pemberian intervensi melalui psikoedukasi manajemen stres. Pendekatan intervensi yang digunakan adalah dengan kognitif behavior karena pada kegiatan ini akan diberikan pengetahuan untuk meningkatkan manajemen stres lansia sehingga dapat mencegah stres. Jumlah responden dalam intervensi ini adalah 11 orang lansia yang menjadi anggota di payuguban lansia Rossela. Teknik sampling yang digunakan adalah purposive sampling, yaitu peneliti telah menentukan kriteria sampel atau responden yang akan diberikan intervensi.

Tingkat stres lansia diukur dengan menggunakan instrumen Stress Assessment Questionnaire dan pengetahuan mengenai manajemen stres diukur menggunakan format

Jurnal Penelitian dan Pengukuran Psikologi, Vol. 8, 1, April 2019 
yang dibuat oleh pemeriksa yang berisikan pertanyaan mengenai manajemen stres.

Hasil keberhasilan intervensi ini diukur dengan analisa uji beda untuk mengetahui perbedaan kondisi pengetahuan lansia mengenai manajemen stres sebelum diberikan intervensi dan sesudah diberikan intervensi.

\section{Hasil Penelitian dan Diskusi}

Berdasarkan data hasil pemeriksaan kondisi pengetahuan lansia terhadap manajemen stres, terdapat perbedaan pengetahuan lansia yaitu adanya peningkatan pengetahuan lansia mengenai manajemen stres sebelum diberikan intervensi dan sesudah diberikan intervensi.

Tabel 1. Hasil Pengisian SAQ

\begin{tabular}{ccc}
\hline Nama (inisial) & Usia & \multicolumn{2}{c}{ Kecenderungan Stres Ya/Tidak } \\
\hline A & 55 & Tidak \\
B & 73 & Tidak \\
C & 65 & Ya \\
D & 59 & Tidak \\
E & 57 & Tidak \\
F & 62 & Tidak \\
G & 62 & Tidak \\
H & 69 & Tidak \\
J & 73 & Tidak \\
K & 69 & Tidak \\
\hline
\end{tabular}

Berdasarkan tabel 1 di atas dapat diketahui kecenderungan tingkat stres lansia yang tergabung dalam Paguyuban Lansia Rossela cukup baik yaitu hanya terdapat satu orang lansia yang mengalami kecenderungan stres berdasarkan perhitungan level stres pada SAQ.

Tabel 2. Hasil Uji - $\mathrm{t}$

Paired Samples Statistics

\begin{tabular}{cccc}
\hline \multicolumn{4}{c}{ Mean N Std. Deviation Std. Error Mean } \\
\hline Pair 1 Pretest & 2.31811 & 2.0405 & .6152 \\
Posttest 4.18211 & 1.5854 & .4780 \\
\hline
\end{tabular}

Pada hasil uji beda melalui Uji - $\mathrm{t}$ terhadap 11 orang peserta intervensi, diperoleh nilai rata-rata hasil pemberian pengetahuan mengenai stres yaitu 2.318 sedangkan untuk nilai posttest diperoleh nilai rata-rata hasil pemberian pengetahuan mengenai stres belajar sebesar 4.182. Hal ini menunjukkan adanya perbedaan nilai pretest dan posttest pada lansia, dimana nilai posttest menunjukkan angka yang lebih tinggi.

Tabel 3. Uji Korelasi

Paired Samples Correlations

\begin{tabular}{ccccc}
\hline & & N & Correlation & Sig. \\
\hline Pair 1 & $\begin{array}{r}\text { Pretest \& } \\
\text { Posttest }\end{array}$ & 11 & .645 & .032 \\
\hline
\end{tabular}

Jurnal Penelitian dan Pengukuran Psikologi, Vol. 8, 1, April 2019 
Pada tabel 3, hasil korelasi antara pretest dan posttest peserta kegiatan yaitu .645, angka tersebut menunjukkan adanya korelasi yang kuat antara hasil pretest dan posttest.

Tabel 4. Uji-t (keputusan)

\begin{tabular}{ccc}
\hline \multicolumn{3}{c}{ Paired Differences } \\
\hline Mean & Sig. (2-tailed) \\
\hline $\begin{array}{c}\text { Pair 1 Pretest- } \\
\text { Posttest }\end{array}$ & -1.8636 & .003 \\
\hline
\end{tabular}

Nilai probabilitas yang terdapat pada tabel diatas adalah .003 atau Sig. (2-tailed) $<0.05$, maka dapat ditarik kesimpulan yaitu terdapat perbedaan yang signifikan antara hasil pretest-posttest mengenai pengetahuan stres pada lansia yang mengikuti kegiatan intervensi sebanyak 11 orang.

Tabel 5. Effect size

\begin{tabular}{cccc}
\hline Input Parameter & $\begin{array}{c}\text { Effect size } \\
\mathrm{dz}\end{array}$ & $\begin{array}{c}\text { Total Sample } \\
\text { Size }\end{array}$ & $\begin{array}{c}\text { Output } \\
\text { Parameter }\end{array}$ \\
\cline { 1 - 3 } & & & Power $(1-\beta$ err prob) \\
\hline Tails (s) & 0.72 & 11 & 0.95 \\
\hline Two & & & \\
\hline
\end{tabular}

Hasil uji effect size pada skor sebelum diberikan intervensi untuk meningkatkan pengetahuan stres (pretest) dan setelah diberikan intervensi (posttest). Effect size digunakan untuk mengetahui besar jarak antara dua skor yang ditunjukkan oleh mean skor tersebut. Berdasarkan Cohen's (d), nilai effect size 0.72 termasuk ke dalam kategori average yang terdapat pada hasil skor skor pretest dan posttest, sedangkan pada hasil statistical power (1- $\beta$ err prob) bernilai 0.95 yang berarti pada variabel ini memiliki kekuatan sebesar $95 \%$ untuk menolak hipotesis nul (H0).

Pada awalnya hasil screening terhadap tingkat stres dan hasil pretest pengetahuan stres lansia yang tergabung dalam Paguyuban Lansia Rossela menunjukkan terdapat satu orang peserta yang memiliki kecenderungan stres dan hampir seluruh peserta tidak memiliki pengetahuan yang cukup mengenai stres akan tetapi setelah dilakukannya intervensi terdapat perbedaan yang signifikan mengenai pengetahuan lansia terhadap stres dan dalam melakukan manajemen stres.
Intervensi yang dilakukan ialah psikoedukasi berupa training dengan cara pemberian leaflet materi stres, penyuluhan mengenai isi materi pada leaflet, dan melakukan praktek cara pencegahan stres melalui metode relaksasi menggunakan SEFT.

Psikoedukasi tersebut dipilih sebagai cara pemeriksa untuk intervensi karena tujuan psikoedukasi ialah untuk meningkatkan pemahaman dan atau keterampilan sebagai usaha pencegahan dari munculnya dan atau meluasnya gangguan psikologis di suatu kelompok, komunitas, atau masyarakat (HIMPSI, 2010), dalam hal ini dilakukan sebagai pencegahan karena pada hasil screening tingkat stres lansia menunjukkan bahwa peserta yang tergabung dalam Paguyuban Lansia Rossela tidak banyak yang memiliki kecenderungan stres.

\section{Kesimpulan}

Berdasarkan hasil intervensi yang diberikan melalui psikoedukasi manajemen stres pada lansia 
di Paguyuban Lansia Rossela, kegiatan intervensi ini memberikan efek yang positif untuk meningkatkan pengetahuan lansia mengenai manajemen stres yaitu data pretest - posstest yang diisi oleh peserta memiliki perbedaan hasil skor pengetahuan lansia setelah mengikuti kegiatan menjadi lebih tinggi dibandingkan sebelum mengikuti kegiatan intervensi.

Hasil observasi pada saat pemberian praktek untuk keterampilan dalam mencegah stres terlihat lansia lebih aktif dibandingkan ketika diberikan penyuluhan mengenai materi pengetahuan stres. Intervensi yang dilakukan memiliki effect size dengan kategori average, hal ini menandakan bahwa kegiatan yang dilakukan cukup memiliki efek yang positif bagi peserta yang mengikuti kegiatan.

\section{Daftar Pustaka}

Altius. (n.d). Stress Assesment Questionnare. People Sense

Hidaayah, N. (n.d.). Stress Pada Lansia Menjadi Faktor Penyebab dan Akibat Terjadinya Penyakit. Skripsi. Surabaya: Universitas Nahdlatul Ulama.
HIMPSI. (2010). Kode Etik Psikologi Indonesia. Jakarta: Pengurus Pusat Himpunan Psikologi Indonesia.

Ismayanti, R., Isnia, P. F., Puspitasari, R., \& Susanti, Y. (2015). Apa itu Lansia? Jurnal. Malang.

Kamus Besar Bahasa Indonesia. (2008). Jakarta: Pusat Bahasa.

Santika, I. G. (2015). Hubungan Indeks Masa Tubuh (IMT) dan Umur Terhadap Daya Tahan Umum (Kardiovaskuler) Mahasiswa Putra Semester II Kelas A Fakulas Pendidikan Olahraga dan Kesehatan IKIP PGRI Bali Tahun 2014. Jurnal Pendidikan Kesehatan Rekreasi, 1.

Segarahayu, R.D. (n.d). Pengaruh Manajemen Stres Terhadap Penurunan Tingkat Stres Pada Narapidana di LPW Malang. Skripsi. Universitas Negeri Malang

Yunitasari, A. (2011). Faktor-Faktor Yang Mempengaruhi Tingkat Stres Pada Lansia Pensiunan Di Wilayah Kerja Puskesmas Pelitakan Kabupaten Polewali Mandar. Skripsi. Universitas Hasanuddin. 